\title{
Association of eNOS Gene Polymorphisms T-786C and G894T With Blood Pressure Variability in Man
}

\author{
M. JÍRA ${ }^{1,2}$, E. ZÁVODNÁ ${ }^{1}$, N. HONZÍKOVÁ ${ }^{1}$, Z. NOVÁKOVÁ ${ }^{1}$, A. VAS̆KŮ $^{3}$, \\ L. IZAKOVIČOVÁ HOLLÁ ${ }^{3}$, B. FIŠER ${ }^{1}$
}

${ }^{1}$ Department of Physiology, Faculty of Medicine, Masaryk University, Brno, Czech Republic, ${ }^{2}$ Department of Surgery, University Hospital Brno and Faculty of Medicine, Masaryk University, Brno, Czech Republic, ${ }^{3}$ Department of Pathological Physiology, Faculty of Medicine, Masaryk University, Brno, Czech Republic

Received September 9, 2009

Accepted May 26, 2010

On-line October 15, 2010

\section{Summary}

The aim of this study was to evaluate the association of single nucleotide polymorphisms (SNPs) T-786C and G894T in the gene encoding eNOS with blood pressure variability (BPV) in man. Blood pressure was recorded beat-to-beat at rest three times in periods of one week ( 5 min, Finapres, breathing at $0.33 \mathrm{~Hz}$ ) in 152 subjects (19-24 years). Systolic (SBPV $\left.0.1 r / \mathrm{SBPV}_{0.1 \mathrm{a}}\right)$ and diastolic $\left(\mathrm{DBPV}_{0.1 \mathrm{r}} / \mathrm{DBPV}_{0.1 \mathrm{a}}\right)$ blood pressure variabilities in relative (r.u.) and absolute $\left(\mathrm{mmHg}^{2} / \mathrm{Hz}\right)$ units were determined by the spectral method as spectral power at the frequency of $0.1 \mathrm{~Hz}$. Genotypes of both polymorphisms were detected using polymerase chain reaction and restriction analysis using enzymes Msp I and Ban II. Significant differences were observed in BPV among genotypes of T-786C SNP ( $p<0.05$; Kruskal-Wallis), and among haplotypes of both SNPs ( $p<0.05$; Kruskal-Wallis) as well. In T-786C SNP, carriers of less frequent allele (CC homozygotes and TC heterozygotes) showed significantly greater $\mathrm{SBPV}_{0.1 \mathrm{r}}$ and $\mathrm{SBPV}_{0.1 \mathrm{a}}$ compared to TT homozygotes (Mann-Whitney; $\mathrm{p}<0.05$ ). The G894T variant showed no significant differences, but, both SNPs were in linkage disequilibrium $\left(D^{\prime}=0.37 ; p<0.01\right)$. Carriers of haplotype CT/CT (CC homozygotes of $-786 \mathrm{C} / \mathrm{T}$ and $T$ homozygotes of G894T) displayed significantly greater $\mathrm{SBPV}_{0.1 r}$, $\mathrm{SBPV}_{0.1 \mathrm{a}}$ and $\mathrm{DBPV}_{0.1 \mathrm{a}}$ compared to carriers of other haplotype combinations (Kruskal-Wallis; $p=0.015, p=0.048$, and $p=0.026$, respectively). In conclusion, the haplotype formed by less frequent alleles of both eNOS variants was associated with increased systolic and diastolic BPV in this study.

\section{Key words}

Arterial blood pressure variability • Spectral analysis • Nitric oxide synthase $\bullet$ Genetics $\bullet$ Polymorphism

\section{Corresponding author}

Nataša Honzíková, Fyziologický ústav LF MU, Komenského nám. 2, 66243 Brno, Czech Republic. Fax: +420-549 493748. E-mail: nhonziko@med.muni.cz

Essential hypertension and other cardiovascular diseases are thought to be multifactorial. Along with external influences the genetic factors play an important role in their pathogenesis. In the last years sample of evidence has been brought that single nucleotide chain polymorphisms (SNPs) T-786C and G894T in the gene coding for endothelial nitric oxide synthase (eNOS) are engaged in the genesis of some cardiovascular disorders such as coronary artery disease (Nakayama et al. 1999, Hingorani et al. 1999), myocardial infarction (Shimasaki et al. 1998), and essential hypertension (Miyamoto et al. 1998). There are data showing that nitric oxide (NO) is involved in the control of blood pressure variability (BPV) (Just et al. 1994, Nafz et al. 1997). In experiments on animals, a block of endogenous NO production by NG-nitro-L-arginine in dogs (Just et al. 1994) and rats (Nafz et al. 1997) led to increased BPV with greatest difference in a frequency range where the sympathetic nervous system is most effective in these species. A

PHYSIOLOGICAL RESEARCH • ISSN 0862-8408 (print) • ISSN 1802-9973 (online)

(c) 2011 Institute of Physiology v.v.i., Academy of Sciences of the Czech Republic, Prague, Czech Republic

Fax+420 241062 164, e-mail: physres@biomed.cas.cz, www.biomed.cas.cz/physiolres 
similar phenomenon was observed in eNOS knock-out mice which displayed greater BPV comparing to controls (Stauss et al. 1999). Thus NO buffers blood pressure fluctuations by opposing the sympathetic nerve activity (Stauss et al. 2000). The activity of the sympathetic nervous system is linked to BPV (Laitinen et al. 1999). Concerning short-term BPV in the frequency range of $0.1 \mathrm{~Hz}$ determined by spectral analysis, it was found that it characterizes a young healthy individual (Hojgaard et al. 1998, Jíra et al. 2010) similarly as heart rate variability (HRV) (Honzíková et al. 1990) and baroreflex sensitivity (BRS) (Jíra et al. 2006). Spectral analysis of BPV enabled detection of differences in baroreceptor regulation of blood pressure, which reflected the altered function of the sympathetic nervous system, between normotensive, borderline hypertensive, and mildly hypertensive individuals (Takalo et al. 1994). BPV at a frequency of $0.1 \mathrm{~Hz}$ increases at an early stage of blood pressure elevation in adolescents (Honzíková et al. 2006).

Although many studies were engaged in the evaluation of the association between SNPs in the eNOS gene and cardiovascular diseases in humans on the one hand and in the buffering effect of NO production on BPV in animals on the other, there is a lack of information about genetic determination of BPV buffering in humans. The aim of this study was to investigate the association between T-786C and G894T SNPs and their combinations (called haplotypes) and short-term BPV at $0.1 \mathrm{~Hz}$ in young healthy population. Veerman et al. (1994) suggested that aging does not merely influence the magnitude of BPV but causes a complex rearrangement of the variability pattern by changes in neurocardiovascular regulation. Similarly, Mancia et al. (1986) showed that BRS is inversely related to BPV and positively related to HRV, supporting the hypothesis that age-related decrease in BRS is based on the age-related thickening of the carotid artery wall (Lábrová et al. 2005). Therefore, the current study was focused on apparently healthy young people, in whom the artery wall is not affected by atherosclerosis, increased intima-media thickness or other pathological processes, which could mask the differences in BPV given by genetic dispositions.

Spontaneous fluctuations in systolic (SBP) and diastolic (DBP) blood pressure were recorded beat-tobeat (Finapres) in 152 young healthy individuals ( 45 men and 107 women) aged 19-24 years after 15 minutes of rest for 5 minutes in sitting position during metronome controlled breathing (20 breaths $/ \mathrm{min})$ three times in periods of one week, in the same daytime. The analyzed individuals were randomly recruited from the students of University. Only apparently healthy individuals were included in the study; all of the subjects were without positive personal history of hypertension, myocardial infarction, stroke or diabetes mellitus, the exclusion criteria also included pathological metabolic profile. Systolic (SBPV) and diastolic blood pressure variabilities (DBPV) were evaluated by spectral analysis (Honzíková et al. 1992) as the values of the power spectra at the frequency of $0.1 \mathrm{~Hz}$ in both absolute $\left(\mathrm{mmHg}^{2} / \mathrm{Hz}\right)$ and relative (r.u.) units $\left(\mathrm{SBPV}_{0.1 \mathrm{r}}, \mathrm{SBPV}_{0.1 \mathrm{a}}, \mathrm{DBPV}_{0.1 \mathrm{r}}\right.$, $\left.\mathrm{DBPV}_{0.1 \mathrm{a}}\right)$. For genetic analysis a sample of blood $(10 \mathrm{ml})$ was taken. DNA was isolated from leukocytes according to a standard procedure. Both SNPs were genotyped using polymerase chain reaction and restriction analysis using enzymes Msp I and Ban II according to a modified original method of Novoradovsky et al. (1999). Statistical analysis was performed using Statistica version 6.0. Variations in the quantitative phenotypes were tested by Kruskal-Wallis analysis of variance or the Mann-Whitney test. The pairwise linkage disequilibrium (LD) among polymorphisms was estimated with the Lewontin disequilibrium coefficient ( $\mathrm{D}^{\prime}$ ). The program PHASE 2.1 developed by Stephens et al. (2001) was used for in silico estimation of haplotype frequencies; differences in haplotype distributions were assessed by a permutation test. The study was approved by the Ethics Committee.

The values of blood pressure of our study group were in a physiological interval (the whole group - SBP: $112.0 \pm 8.0 \mathrm{mmHg}$, DBP: $64.0 \pm 6.0 \mathrm{mmHg}$; males - SBP: $114.0 \pm 8.0 \mathrm{mmHg}$, DBP: $65.0 \pm 7.0 \mathrm{mmHg}$; females SBP: $112.0 \pm 7.0 \mathrm{mmHg}$, DBP: $64.0 \pm 5.0 \mathrm{mmHg}$ ). The frequency of genotypes was $40.13 \%$ (TT, $\mathrm{n}=61$ ), $46.05 \%(\mathrm{CT}, \mathrm{n}=70), 13.82 \%(\mathrm{CC}, \mathrm{n}=21)$ for $\mathrm{T}-786 \mathrm{C}$ SNP and $56.58 \%(\mathrm{GG}, \mathrm{n}=86), 36.84 \%(\mathrm{GT}, \mathrm{n}=56)$, $6.58 \%(\mathrm{TT}, \mathrm{n}=10)$ for G894T SNP. A significant difference in $\mathrm{SBPV}_{0.1 \mathrm{a}}$ among genotypes of $\mathrm{T}-786 \mathrm{C}$ polymorphism was found (TT: $43.3 \pm 23.3$, TC: $57.9 \pm 35.7$, CC: $52.0 \pm 27.2 \mathrm{mmHg}^{2} / \mathrm{Hz}$; non-parametric KruskalWallis test for multiple comparisons of independent samples; $p<0.05$ ). The carriers of less frequent allele (CC homozygotes and TC heterozygotes) showed significantly greater $\mathrm{SBPV}_{0.1 \mathrm{r}}$ and $\mathrm{SBPV}_{0.1 \mathrm{a}}$ compared to $\mathrm{TT}$ homozygotes $\left(\mathrm{SBPV}_{0.1 \mathrm{r}}-\mathrm{CC}+\mathrm{TC}: 0.022 \pm 0.010\right.$, TT: $0.019 \pm 0.009$ r.u. and $\mathrm{SBPV}_{0.1 \mathrm{a}}-\mathrm{CC}+\mathrm{TC}: 56.6 \pm 33.9$, TT: $43.3 \pm 23.3 \quad \mathrm{mmHg}^{2} / \mathrm{Hz}$; Mann-Whitney test with Bonferroni-Holm correction; $\mathrm{p}<0.05$ ). There was no significant difference in BPV among carriers of different 
Table 1. Differences in BP and BPV among haplotypes of T-786C and G894T SNPs.

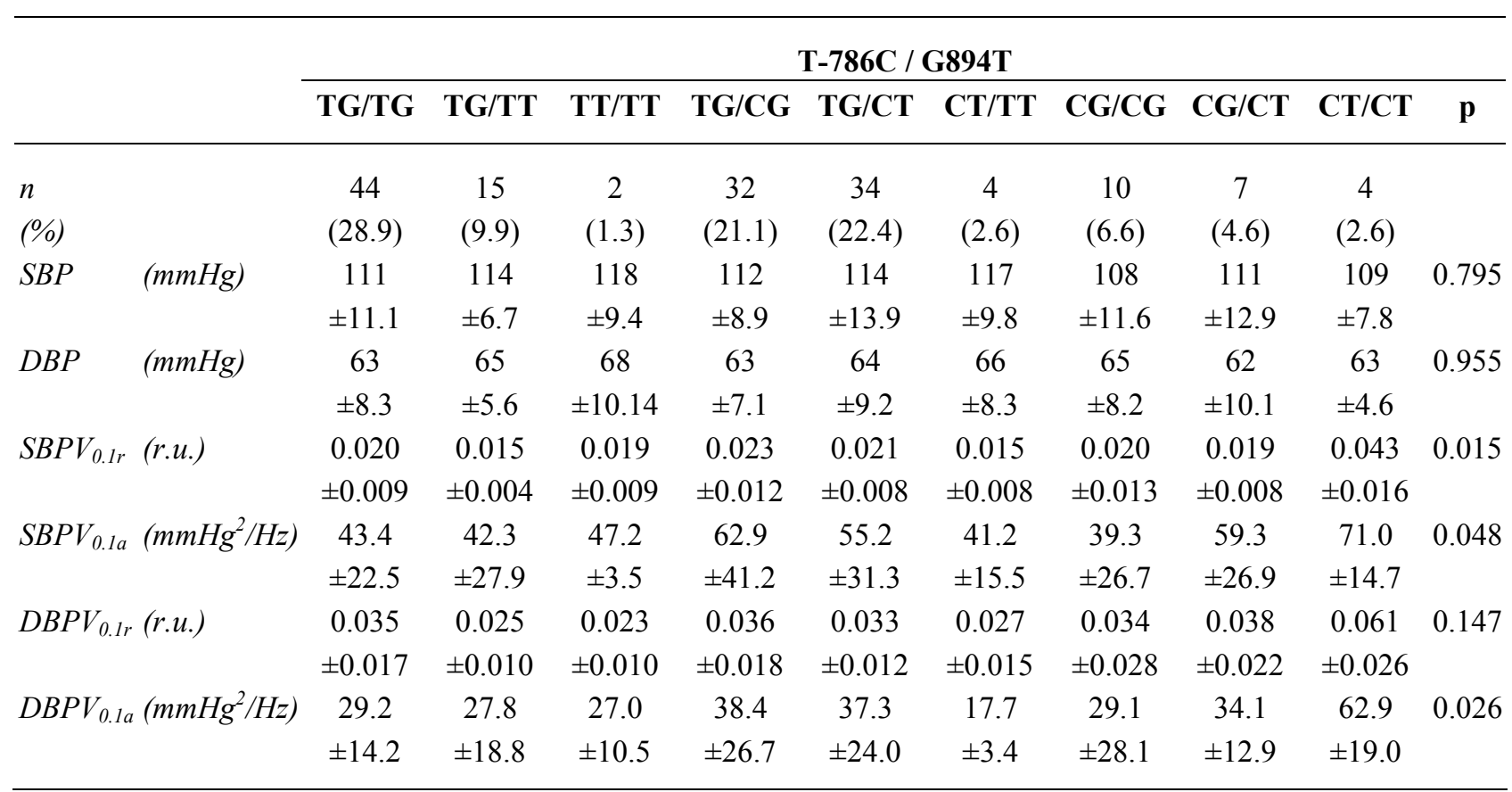

Means \pm standard deviation: SBP, systolic blood pressure; DBP, diastolic blood pressure; $\mathrm{SBPV}_{0.11}$, systolic blood pressure variability in relative units; $\mathrm{SBPV}_{0.1 a}$, systolic blood pressure variability in absolute units; $\mathrm{DBPV}_{0.11}$, diastolic blood pressure variability in relative units; $\mathrm{DBPV}_{0.1 \mathrm{a}}$, diastolic blood pressure variability in absolute units; $\mathrm{p}$, $\mathrm{p}$-level (non-parametric Kruskal-Wallis test for multiple comparisons of independent samples); $n$, number of subjects

genotypes of G894T polymorphism. The SNPs were in linkage disequilibrium $\left(\mathrm{D}^{\prime}=0.37 ; \mathrm{p}<0.01\right)$. However, since it is known that interaction between different variants in the eNOS gene can be important for its function, we constructed the haplotypes with both selected SNPs in this gene and tested their effects. The total frequencies of eNOS haplotypes in our study sample were the following: TG (53.2\%), CG (21.8\%), CT (15.1\%), and TT (9.9\%). Significant differences in BPV among haplotypes of both SNPs were found. The subjects with haplotype $\mathrm{CT} / \mathrm{CT}$, i. e. homozygous for less frequent allele in both SNPs (carriers of CC for T-786C and of TT for G894T) displayed significantly greater $\mathrm{SBPV}_{0.1 \mathrm{r}}$, $\mathrm{SBPV}_{0.1 \mathrm{a}}$ and $\mathrm{DBPV}_{0.1 \mathrm{a}}$ compared to carriers of other haplotype combinations (Table 1). For this subgroup of $\mathrm{CT} / \mathrm{CT}$ carriers a tendency towards greater values of $\mathrm{DBPV}_{0.1 \mathrm{r}}$ was observed, but the difference in $\mathrm{DBPV}_{0.1 \mathrm{r}}$ among them and the carriers of other genotype combinations was insignificant. There was no significant difference in blood pressure among carriers of different haplotypes of the studied polymorphisms. No significant difference in BPV between males and females was found. No correlation of BPV with age was observed, either.

Although many studies have been engaged in BPV explanation, there is still lack of data about its genetic basis. In this study we reported that polymorphisms T-786C and G894T in the gene coding for eNOS influence the level of short-term BPV. We showed that T-786C SNP caused a rise in SBPV in a frequency range of $0.1 \mathrm{~Hz}$. Moreover, the $\mathrm{CT} / \mathrm{CT}$ haplotype (combination of homozygote genotypes of less frequent alleles of both SNPs) was associated with an increase in the values of both SBPV and DBPV. Taken into account that SNPs were in linkage disequilibrium this suggests that the influence of these SNPs on BPV should be interactive. As the impact of both SNPs on BPV refers to a frequency range of $0.1 \mathrm{~Hz}$, one can assume that not only decreased baroreflex sensitivity but also decreased buffering capacity of the eNOS/NO system may cause enhanced BPV. The results of this study are in agreement with studies on animals (Nafz et al. 1997, Stauss et al. 1999, Stauss et al. 2000). The T786C SNP is located at the site of the gene binding the negative transcriptional factor RPA1, which has a greater affinity to the $-786 \mathrm{C}$ variant (Miyamoto et al. 2000). RPA1-raised coupling to this regulatory region causes a decreased activity of the promoter and thus can decrease eNOS transcription. In G894T SNP the 894T variant is subjected to enhanced intracellular cleavage and leads to decreased intracellular concentration of the enzyme (Tesauro et al. 2000). Since the detected SNPs can affect eNOS transcription rate, concentration or activity, a 
decreased NO production leading to decreased eNOS/NO system effectiveness to buffer blood pressure fluctuations can result. This could be a possible explanation of the increased blood pressure variability observed in CT/CT haplotype carriers. There are some limitations of this study that need to be considered. For the multifactorial heredity (characteristic not only of cardiovascular diseases but also of determination of physiological parameters, e.g. baroreflex sensitivity), it is typical that each genetic polymorphism has generally only a small effect, and that the interaction of gene variants with environmental factors can potentially affect the observed phenotype. In addition, eNOS polymorphisms might be in linkage disequilibrium with other functional SNPs found elsewhere in this gene. The relatively small number of subjects in some subgroups and an unbalanced number of males and females in the study group is vulnerable to type I error.

In conclusion, we found significant associations of haplotypes of T-786C and G894T polymorphisms in the gene encoding eNOS with systolic and diastolic blood pressure variability. These results need verification and additional studies will be necessary for better understanding of the interaction effects of genetic factors in determination of haemodynamic parameters.

\section{Conflict of Interest}

There is no conflict of interest.

\section{Acknowledgements}

Supported by grant MSM 0021622402.

\section{References}

HINGORANI AD, LIANG CF, FATIBENE J, LYON A, MONTEITH S, PARSONS A, HAYDOCK S, HOPPER RV, STEPHENS NG, O'SHAUGHNESSY KM, BROWN MJ: A common variant of the endothelial nitric oxide synthase (Glu298Asp) is a major risk factor for coronary artery disease in the UK. Circulation 100: 1515-1520, 1999.

HONZÍKOVÁ N, PEŇÁZ J, FIŠER B: Individual features of circulatory power spectra in man. Eur J Appl Physiol Occup Physiol 59: 430-434, 1990.

HONZÍKOVÁ N, FIŠER B, HONZÍK J: Noninvasive determination of baroreflex sensitivity in man by means of spectral analysis. Physiol Res 41: 31-37, 1992.

HONZÍKOVÁ N, NOVÁKOVÁ Z, ZÁVODNÁ E, PADEROVÁ J, LOKAJ P, FIŠER B, BALCÁRKOVÁ P, HRSTKOVÁ H: Baroreflex sensitivity in children, adolescents, and young adults with essential and white-coat hypertension. Klin Pädiatr 218: 237-242, 2006.

HOJGAARD MV, HOLSTEIN-RATHLOU NH, ANGER E, KANTERS JK: Short-term reproducibility of heart rate variability, systolic blood pressure variability, and the transfer function of blood pressure and heart rate. Hypertension 32: 801, 1998.

JÍRA M, ZÁVODNÁ E, HONZÍKOVÁ N, NOVÁKOVÁ Z, FIŠER B: Baroreflex sensitivity as an individual characteristic feature. Physiol Res 55: 349-351, 2006.

JÍRA M, ZÁVODNÁ E, NOVÁKOVÁ Z, FIŠER B, HONZÍKOVÁ N: Reproducibility of blood pressure and inter-beat interval variability in man. Physiol Res 59 (Suppl 1): S113-S121, 2010.

JUST A, WITTMANN U, NAFZ B, WAGNER CD, EHMKE H, KIRCHHEIM HR, PERSSON PB: The blood pressure buffering capacity of nitric oxide by comparison to the baroreceptor reflex. Am J Physiol 267: H521H527, 1994.

LÁBROVÁ R, HONZÍKOVÁ N, MADĚROVÁ E, VYSOČANOVÁ P, NOVÁKOVÁ Z, ZÁVODNÁ E, FIŠER B, SEMRÁD B: Age-dependent relationship between the carotid intima-media thickness, baroreflex sensitivity, and the inter-beat interval in normotensive and hypertensive subjects. Physiol Res 54: 593-600, 2005.

LAITINEN T, HARTIKAINEN J, NISKANEN L, GEELEN G, LÄNSIMIES E: Sympathovagal balance is major determinant of short-term blood pressure variability in healthy subjects. Am J Physiol 276: H1245-H1252, 1999.

MANCIA G, PARATI G, POMIDOSSI G, CASADEI R, DI RIENZO M, ZANCHETTI A: Arterial baroreflexes and blood pressure and heart rate variabilities in humans. Hypertension 8: 147-153, 1986. 
MIYAMOTO Y, SAITO Y, KAJIYAMA N, YOSHIMURA M, SHIMASAKI Y, NAKAYAMA M, KAMITANI S, HARADA M, ISHIKAWA M, KUWAHARA K, OGAWA E, HAMANAKA I, TAKAHASHI N, KANESHIGE T, TERAOKA H, AKAMIZU T, AZUMA N, YOSHIMASA Y, YOSHIMASA T, ITOH H, MASUDA I, YASUE H, NAKAO K: Endothelial nitric oxide synthase gene is positively associated with essential hypertension. Hypertension 32: 3-8, 1998.

MIYAMOTO Y, SAITO Y, NAKAYAMA M, SHIMASAKI Y, YOSHIMURA T, YOSHIMURA M, HARADA M, KAJIYAMA N, KISHIMOTO I, KUWAHARA K, HINO J, OGAWA E, HAMANAKA I, KAMITANI S, TAKAHASHI N, KAWAKAMI R, KANGAWA K, YASUE H, NAKAO K: Replication protein A1 reduces transcription of the endothelial nitric oxide synthase gene containing a -786T $\mathrm{C}$ mutation associated with coronary spastic angina. Hum Mol Genet 9: 2629-2637, 2000.

NAFZ B, WAGNER CD, PERSSON PB: Endogenous nitric oxide buffers blood pressure variability between $0.2 \mathrm{~Hz}$ and $0.6 \mathrm{~Hz}$ in the conscious rat. Am J Physiol 272: H632-H637, 1997.

NAKAYAMA M, YASUE H, YOSHIMURA M, SHIMASAKI Y, KUGIYAMA K, OGAWA H, MOTOYAMA T, SAITO Y, OGAWA Y, MIYAMOTO Y, NAKAO K: T(-786) C mutation in the 5'-flanking region of the endothelial nitric oxide synthase gene is associated with coronary spasm. Circulation 99: 2864-2870, 1999.

NOVORADOVSKY A, BRANTLY ML, WACLAWIW MA, CHAUDHARY PP, IHARA H, QI L, EISSA NT, BARNES PM, GABRIELE KM, EHRMANTRAUT ME, ROGLIANI P, MOSS J: Endothelial nitric oxide synthase as a potential susceptibility gene in the pathogenesis of emphysema in $\alpha 1$-antitrypsin deficiency. Am $J$ Respir Cell Mol Biol 20: 441-447, 1999.

SHIMASAKI Y, YASUE H, YOSHIMURA M, NAKAYAMA M, KUGIYAMA K, OGAWA H, HARADA E, MASUDA T, KOYAMA W, SAITO Y, MIYAMOTO Y, OGAWA Y, NAKAO K: Association of the missense Glu298Asp variant of the endothelial nitric oxide synthase gene with myocardial infarction. $J A m$ Coll Cardiol 31: 1506-1510, 1998.

STAUSS HM, GÖDECKE A, MROWKA R, SCHRADER J, PERSSON PB: Enhanced blood pressure variability in eNOS knockout mice. Hypertension 33: 1359-1363, 1999.

STAUSS HM, PERSSON PB: Role of nitric oxide in buffering short-term blood pressure fluctuations. News Physiol Sci 15: 229-233, 2000.

STEPHENS M, SMITH N, DONNELLY P: A new statistical method for haplotype reconstruction from population data. Am J Hum Gen 68: 978-989, 2001.

TAKALO R, KORHONEN I, TURJANMAA V, MAJAHALME S, TUOMISTO M, UUSITALO A: Short-term variability of blood pressure and heart rate in borderline and mildly hypertensive subjects. Hypertension 23 : 18-24, 1994.

TESAURO M, THOMPSON WC, ROGLIANI P, QI L, CHAUDHARY PP, MOSS J: Intracellular processing of endothelial nitric oxide synthase isoforms associated with differences in severity of cardiopulmonary diseases: cleavage of proteins with aspartate vs. glutamate at position 298. Proc Natl Acad Sci USA 97: 2832-2835, 2000.

VEERMAN DP, IMHOLZ BPM, WIELING W, KAREMAKER JM, VAN MONTFRANS GA: Effects of aging on blood-pressure variability in resting conditions. Hypertension 24: 120-130, 1994. 